\title{
Pogrzeb i grób w tradycjach o patriarchach zawartych w Księdze Rodzaju. Stan badań ${ }^{2}$
}

Bóg, stwarzając świat, obdarzył człowieka życiem. Jednak przez grzech będący wyrazem nieposłuszeństwa wobec Boga pojawiła się śmierć jako jego konsekwencja. Od tego momentu stała się nieuniknioną rzeczywistością, która prędzej czy później dosięga każdego człowieka. Stary Testament jedynie w przypadku dwóch osób wskazuje na pominięcie etapu śmierci fizycznej przy przechodzeniu do łączności z Bogiem (Henoch [Rdz 5,24] oraz Eliasz [2 Krl 2,11]). Nie jest więc niczym dziwnym, że temat końca życia człowieka pojawia się na kartach Biblii.

W pierwszych jedenastu rozdziałach Księgi Rodzaju informacja o śmierci ogranicza się do prostego stwierdzenia, że dana osoba umarła (genealogia Setytów [Rdz 5] oraz śmierć Noego [Rdz 9,26]). W wypadku genealogii ludzkości popotopowej informacja o śmierci ma charakter jedynie pośredni - wynika z podania liczby przeżytych lat. Dopiero w genealogii Teracha, w zakończeniu

\footnotetext{
${ }^{1}$ Ksiądz dr Maciej Basiuk - ur. w 1971 roku w Rudzie Śl., adiunkt w Katedrze Teologii Biblijnej Starego i Nowego Testamentu Wydziału Teologicznego Uniwersytetu Śląskiego w Katowicach. Członek Stowarzyszenia Biblistów Polskich. Zainteresowania naukowe: Księga Rodzaju (zwłaszcza historia patriarchów). Najważniejsza publikacja: Ofiara Izaaka (Rdz 22,1-14) w zachodniej tradycji patrystycznej; e-mail: maciej.basiuk@us.edu.pl. ORCID: 0000-0001-5844-3259.

${ }^{2}$ Artykuł powstał wskutek realizacji działania 2017/01/X/HS1/00850 finansowanego przez Narodowe Centrum Nauki. Fragmenty niniejszej publikacji zostały wykorzystane w artykule Pogrzeb i grób w tradycjach o patriarchach zawartych w Księdze Rodzaju. Status quaestionis, który ukaże się w nierecenzowanym periodyku „Zeszyty Naukowe Stowarzyszenia Biblistów Polskich”, jako wersja drukowana referatu o tym samym tytule wygłoszonego 19 września 2018 roku w ramach 56. Sympozjum Biblistów Polskich, które odbyło się 18-19 września 2018 roku w Wyższym Seminarium Duchownym w Łomży.
} 
jedenastego rozdziału, informacji o śmierci Harana i Teracha towarzyszy dodatkowo wskazanie miejsca, w którym do niej doszło ( $\operatorname{Rdz} 11,28.32)$.

Sytuacja zmienia się w części poświęconej życiu patriarchów. Znajdują się tutaj co prawda również teksty jedynie informujące o śmierci konkretnej osoby (poszczególnych królów Edomu, synów i żony Judy, piekarza faraona), ale w odniesieniu do głównych bohaterów oraz osób z nimi związanych wiadomości o śmierci towarzyszą dodatkowe dane dotyczące m.in. pogrzebu i miejsca pochówku. W formie bezpośredniej przekazane są w odniesieniu do patriarchów: Abrahama (Rdz 25,9-10), Izaaka (Rdz 35,29), Jakuba (Rdz 50,1-13), Józefa (Rdz 50,26), a także Sary (Rdz 23,2-19) i Racheli (Rdz 35,19-20). Autor Księgi Rodzaju wspomina również o śmierci Izmaela $(\operatorname{Rdz} 25,17)$ i Debory — piastunki Rebeki (Rdz 35,8) — w tym wypadku jako miejsce pochówku zostaje wskazane Betel. Poza tym pośrednio pojawia się informacja o pochowaniu Rebeki i Lei w grobowcu rodzinnym na polu Makpela w Hebronie (Rdz 49,31).

Już samo zestawienie tych informacji jest sygnałem, że wzmianki dotyczące śmierci patriarchów rozbudowane o towarzyszące im dane na temat pogrzebu i miejsca pochówku wyróżniają się na tle innych podobnych tekstów w Księdze Rodzaju. Rodzi to oczywiste pytanie, w jakim stopniu dotyczące ich narracje pozostają ze sobą w zależności. Czy łączy je jedynie to, że mówią o śmierci protoplastów Izraela i towarzyszących im wydarzeniach? Czy mają znaczenie szersze, wnoszące nową wartość w teologię Księgi Rodzaju, a może nawet całej Biblii?

W niniejszym artykule poddano analizie istniejące już opracowania odnoszące się do problematyki mówiącej o śmierci patriarchów i towarzyszących jej wydarzeniach (pogrzeb, żałoba, grób), aby sprawdzić, jak dalece całościowo podchodzą do tej praktyki. Nie będzie jednak prowadzona szczegółowa egzegeza tych tekstów, ponieważ każdemu z nich poświęcono mniej lub więcej miejsca w komentarzach do Księgi Rodzaju, które objaśniają je, korzystając z różnych metod badawczych ${ }^{3}$. Wielu wskazanym wyżej perykopom poświęcono osobne artykuły czy monografie badające je w całości lub komentujące konkretny fragment ${ }^{4}$. Często brakuje w nich wskazania punktów stycznych z innymi narracjami

${ }^{3}$ Można wśród nich odnaleźć komentarze bazujące raczej na analizie diachronicznej: J. Skinner, A Critical and Exegetical Commentary on Genesis, Edinburgh 1951; S. Lach, Ksiega Rodzaju. Wstęp — przekład z oryginatu — komentarz, Poznań 1962; H. Gunkel, Genesis, Göttingen 1964'; C. Westermann, Genesis 12-50, Neukirchen-Vluyn 1981; G.W. Coats, Genesis with an Introduction to Narrative Literature, Grand Rapids 1983. Z kolei podejście synchroniczne do badanych tekstów prezentują m.in.: N.M. Sarna, Genesis, Philadelphia 1989; G.J. Wenham, Genesis 16-50, Dallas 1994; V.P. Hamilton, The Book of Genesis. Chapters 18-50, Grand Rapids 1995; K.A. Mathews, Genesis 11:27-50:26, Nashville 2005; J. Lemański, Księga Rodzaju. Rozdziaty 11,27-36,43. Wstęp, przekład z oryginatu, komentarz, Częstochowa 2014; tenże, Księga Rodzaju. Rozdziały 37-50. Wstęp, przekład z oryginatu, komentarz, Częstochowa 2015.

${ }^{4}$ Wśród opracowań odnoszących się do całych perykop warto wskazać: J.S. Bray, Genesis 23 - A Priestly Paradigm for Burial, ,Journal for the Study of the Old Testament” 60 (1993), 
lub są one traktowane marginalnie, dlatego w tym przedłożeniu zostaną poddane analizie jedynie opracowania, które wskazują na istnienie powiązań lub zależności pomiędzy przynajmniej dwoma z wymienionych wyżej tekstów. Wydaje się jednak zasadne rozpoczęcie prowadzonych analiz od ukazania stanu badań odnoszących się do odkryć archeologicznych poświęconych terenowi związanemu ze śmiercią patriarchów. Taki zabieg pomoże w szerszym spojrzeniu na badaną problematykę, a jednocześnie wskaże, $w$ jakim zakresie tekst biblijny jest zgodny $\mathrm{z}$ tym, co jest materialną pozostałością po przodkach.

\section{Grobowiec patriarchów w Hebronie}

Pierwszą kwestią, która nasuwa się osobom znającym Ziemię Świętą, gdy słyszą stwierdzenie „grób patriarchów”, jest istniejące do dziś sanktuarium w Hebronie ukazywane według tradycji jako miejsce pochówku Abrahama, Izaaka i Jakuba oraz ich żon: Sary, Rebeki i Lei. Monumentalna budowla, która wykazuje pewne podobieństwa do świątyni jerozolimskiej, pochodzi niezaprzeczalnie z czasów herodiańskich. Została ona gruntownie przebadana przez włoskiego archeologa Ermete Pierottiego w latach 1854-1861 oraz w roku $1919^{5}$ przez Louisa-Huguesa Vincenta oraz Ernesta J.H. Mackaya. Owocem prac jest monografia opisująca to miejsce, w której są zawarte nie tylko wyniki prowadzonych badań archeologicznych, ale jest przedstawiona historia tego miejsca ${ }^{6}$. Niestety żadna $\mathrm{z}$ tych ekspedycji badawczych nie otrzymała pozwolenia od sprawujących pieczę nad tym stanowiskiem wyznawców islamu na przebadanie grot znajdujących się pod sanktuarium. Najważniejsze więc miejsce, które mogłoby potwierdzić prawdzi-

s. 69-73; J. Berman, Identity Politics and the Burial of Jacob (Genesis 50:1-14), „The Catholic Biblical Quarterly" 68 (2006) 1, s. 11-31; J. Lemański, Grób jako znak prawa własności ziemi? $R d z 23$ i jego przestanie teologiczne, „Roczniki biblijne” 1 (2009), s. 127-153; K.D. Lee, The death of Jacob. Narrative conventions in Genesis 47.28-50.26, Leiden 2016. Z kolei tematem poddanym szczegółowym badaniom była kwestia wskazania źródeł, z jakich mógł czerpać opis zakupu ziemi przez Abrahama, o czym piszą: M.R. Lehmann, Abraham's Purchase of Machpelah and Hittite Law, „Bulletin of the American Schools of Oriental Research” 129 (1953), s. 15-18; G.M. Tucker, The Legal Background of Genesis 23, „Journal of Biblical Literature” 85 (1966), s. 77-84; N. MacDonald, Driving a Hard Bargain? Genesis 23 and Models of Economic Exchange [w:] Anthropology and Biblical Studies. Avenues of Approach, ed. by L.J. Lawrence, M.I. Aguilar, Leiden 2004, s. 79-96; S.C. Russell, Abraham's Purchase of Ephron's Land in Anthropological Perspective, „Biblical Interpretation” 21 (2013) 2, s. 153-170.

${ }^{5}$ Zdaniem Charlesa Fredericka Arden-Close'a w końcowych miesiącach 1919 roku zostało wydane pozwolenie, natomiast same prace badawcze trwały od 26 stycznia do 2 lutego 1920 roku. Zob. tenże, The Cave of Machpelah, „Palestine Exploration Quarterly” 82 (1950) 1, s. 69-77, tu: s. 73.

${ }^{6}$ L.H. Vincent, E.J.H. Mackay, Hebron - Le Haram el-Khalíl - Sépulture des Patriarches, Paris 1923. 
wość relacji wydarzeń odnoszących się do śmierci patriarchów w Piśmie Świętym, wciąż oczekuje na przeprowadzenie badań archeologicznych.

Obecnie dostępne są jedynie zapiski średniowieczne opisujące te groty, m.in. pochodzące od mnicha imieniem Arnold. W XX wieku podjęto dwie skuteczne próby dotarcia do grot. W roku 1967, podczas tzw. wojny sześciodniowej, izraelski minister obrony Mosze Dajan, który był archeologiem-amatorem, pod pozorem względów bezpieczeństwa kazał wszystkim opuścić sanktuarium i pod osłoną nocy przez otwór służący do opuszczania lamp do groty pod sanktuarium opuścił dwunastoletnią dziewczynkę Michal Arbel. Powróciwszy na powierzchnię, opisała ona okrągłą pustą komnatę, w której się znalazła, a także 17-metrowy korytarz zakończony schodami prowadzącymi do góry, zablokowany głazem? Z kolei w 1981 roku dr Seev Jevin pokonał zablokowane wejście, do którego doszła Michal. Korytarzem dotarł do okrągłej pustej komnaty i na jej posadzce zauważył przykrywającą coś pokrywę. Po jej usunięciu przez odkryty otwór dostał się do znajdującego się poniżej pomieszczenia, które było połączone $\mathrm{z}$ jeszcze jedną mniejszą jaskinią. Relacjonował znalezione w tym miejscu pozostałości pochodzące ze starożytności (miałyby być datowane nawet na czasy patriarchów) oraz średniowieczne dzbany, które miałyby potwierdzać informację podaną przez Arnolda, że kości patriarchów zostały poddane kąpieli w płynie mającym je oczyścić i zakonserwować ${ }^{8}$. Niestety wszystkie dostępne informacje pochodzą ze źródeł popularnonaukowych lub popularnych, natomiast nie powstało jak dotąd żadne opracowanie naukowe dotyczące tych dwóch wizyt w grotach pod sanktuarium w Hebronie?

W związku z tym miejscem oraz z kwestią dokładnego ustalenia jego lokalizacji warto zwrócić uwagę na opracowanie Vincenta, które najpierw ukazało się jako artyku1 ${ }^{10}$, a następnie zostało włączone, jako osobny rozdział, we wspomnianą już monografię poświęconą Hebronowi ${ }^{11}$. Zadaniem opracowania Vincenta było potwierdzenie lokalizacji istniejącego sanktuarium na bazie danych, które można odnaleźć w tekście biblijnym, dlatego w początkowej części artykułu bardzo wyraźnie polemizuje on ze stanowiskiem szkoły historyczno-kry-

${ }^{7}$ N. Miller, Patriarchal Burial Site Explored for First Time in 700 Years, ,Biblical Archaeology Review" 11 (1995) 3, s. 26-30, 34-43, tu: s. 42-43; J.P. Free, H.F. Vos, Archaeology and Bible History, Grand Rapids 1992, s. 62.

${ }^{8}$ News Agency NAI, Hidden Until Now: Abraham's Burial Site, [online] http://www.khouse. org/articles/1997/13/ [12.09.2018].

${ }^{9}$ Poza wykorzystanymi wyżej opracowaniami wiele cennych informacji można znaleźć na stronie internetowej poświęconej Hebronowi (http://en.hebron.org.il/), zwłaszcza w zakładce „History".

${ }^{10}$ L.H. Vincent, La sepulture des Patriarches d'apres la Bible, „Revue Biblique” 29 (1920) 4, s. $507-539$.

${ }^{11}$ L.H. Vincent, E.J.H. Mackay, Hebron..., s. 117-144. 
tycznej. Zdaniem Vincenta nie należy pozbawiać realnej wartości historycznej danych zawartych w Piśmie Świętym. Jako jeden z ważniejszych argumentów w dyskusji przytacza stwierdzenie jednego z głównych przedstawicieli nurtu egzegezy historyczno-krytycznej, Juliusa Wellhausena: „[j]eśli tylko tradycja izraelska jest możliwa, szaleństwem byłoby przedkładanie ponad nią jakiejś innej możliwości"12.

Dalsza część tego artykułu zawiera egzegezę Rdz 23, która została przeprowadzona w sposób szczątkowy - mianowicie autor wyjaśnia jedynie te kwestie ${ }^{13}$, które będą przydatne w analizach najważniejszej części poświęconej kwestii położenia hipogeum oraz jego pierwotnego wyglądu ${ }^{14}$. Całość opracowania kończy omówienie nawiązań biblijnych do miejsca pochówku patriarchów, aż do epoki herodiańskiej ${ }^{15}$. Przeprowadzone analizy doprowadziły Vincenta do stanowczego stwierdzenia, że istniejące współcześnie sanktuarium znajduje się dokładnie w miejscu, gdzie był grób patriarchów ${ }^{16}$.

\section{Znaczenie teologiczne zakupu pola z pieczarą Makpela}

Warto zwrócić uwagę na pewne stwierdzenie Vincenta o charakterze teologicznym pojawiające się w prowadzonych przez niego rozważaniach. Mianowicie uważa on, że zakup ziemi na grób dla Sary miałby być pierwszą realizacją Bożej obietnicy odnoszącej się do ziemi danej Abrahamowi podczas jego powołania ${ }^{17}$. Jest to stanowisko przyjmowane przez wielu egzegetów ${ }^{18}$ i właśnie zbadaniu relacji istniejącej pomiędzy Rdz 23 a tematem ziemi obiecanej poświęcił swój artykuł Janusz Lemański ${ }^{19}$. Prowadzone przez niego badania polegające na szczegółowej egzegezie Rdz 23 doprowadziły go do stwierdzenia, że pierwszorzędnym celem tej narracji „,nie było bezpośrednie odniesienie do obietnicy ziemi, tak aby

12 J. Wellhausen, Komposition des Hexateuch, s. 346, za: L.H. Vincent, La sepulture ..., s. 511 (thum. E. Krzywda).

${ }^{13}$ Elementy, które zostają omówione, to po pierwsze uściślenia znaczenia Kiriat-Arba i jego relacji z Mamre i Hebronem (L.H. Vincent, La sepulture..., s. 513-514), następnie ustalenie, kto się kryje pod określeniem „synowie Cheta” (tamże, s. 515-517) i po trzecie kwestia prowadzonych przez Abrahama negocjacji skutkujących zawarciem umowy oraz sprawa położenia jaskini będącej przedmiotem transakcji (tamże, s. 517-518).

14 Tamże, s. 525-533.

15 Tamże, s. 533-539.

16 Tamże, s. 539.

17 Tamże, s. 522.

18 Por. S. Łach, Księga Rodzaju ..., s. 397; B.K. Waltke, Genesis. A Commentary, Grand Rapids 2001, s. 321-322; J. McKeown, Genesis, Grand Rapids 2008, s. 252.

19 J. Lemański, Grób..., s. 128. 
uzasadnić późniejsze jej posiadanie, ale uwydatnienie sposobu obchodzenia się ze zmarłymi"'20.

Z kolei zdaniem Jasona S. Braya narracja zawarta w Rdz 23 stanowi kapłański paradygmat odnoszący się do pogrzebów w Księdze Rodzaju. Jego argumentacja bazuje na dwóch faktach. Po pierwsze opowiadanie o pogrzebie Sary jest pierwszym, jakie pojawia się w Biblii. Po drugie struktura pozostałej części Księgi Rodzaju ma wspierać to stanowisko, ponieważ każdy pogrzeb (poza pochówkiem Racheli) odnosi się do tego pierwszego ${ }^{21}$. Niestety na tym kończy się jego wywód, gdyż resztę opracowania poświęca kwestii kultu zmarłych, a konkretnie wykazaniu, że nie był on praktykowany w Izraelu ani również nie wynika w żaden sposób z Rdz $23^{22}$.

Łukasz Niesiołowski-Spanò twierdzi, że opowiadanie o nabyciu groty Makpela ma charakter etiologiczny wskazujący na prawo Izraelitów do tego terytorium. Jednak pozostaje dla niego kwestią otwartą, kiedy powstała związana z tym wydarzeniem tradycja - czy w czasach Pierwszej Świątyni, czy może w czasie wygnania babilońskiego, a może po jego zakończeniu? Jego propozycje sięgają aż czasów hasmonejskich — jest to stanowisko, za którym sam się opowiada ${ }^{23}$.

\section{Struktura lącząca cykle opowiadań poświęconych Abrahamowi, Izaakowi i Jakubowi}

Według komentatorów historia Abrahama zawiera się głównie między jego powołaniem przez Boga w Charanie (Rdz 12,1-5) a ofiarą Izaaka (Rdz 22) ${ }^{24}$. Natomiast dalsza jego historia przedstawiona w kolejnych rozdziałach traktowana jest jako dodatek i właśnie w kontekście uzasadnienia umieszczenia opisu śmierci patriarchy w miejscu, w którym się on znajduje, Gordon J. Wenham wskazuje na następujące podobieństwa występujące w cyklach poświęconych Abrahamowi, Izaakowi i Jakubowi:

20 Tamże, s. 151.

${ }^{21}$ J.S. Bray, Genesis $23 \ldots$, s. 70.

22 Tamże, s. 70-73.

${ }^{23}$ Ł. Niesiołowski-Spanò, Mityczne początki miejsc świętych $w$ Starym Testamencie, Warszawa 2003, s. 142-143.

${ }^{24}$ Por. G. von Rad, Genesis. A Commentary (Revised edition), Philadelphia 1972, s. 246; W. Brueggemann, Genesis, Louisville 1982, s. 194-195; B.K. Waltke, Genesis ..., s. 311; D.W. Cotter, Genesis, Collegeville 2003, s. 158-159. Inne zdanie w tej kwestii prezentuje Thomas L. Brodie, który twierdzi, że rozdziały 22 i 23 tworzą kompozycyjną strukturę mającą na celu ukazanie postawy Abrahama wobec śmierci (potencjalnej w przypadku Izaaka i rzeczywistej w odniesieniu do Sary); zob. tenże, Genesis as Dialogue. A Literary, Historical, and Theological Commentary, New York 2001, s. 265-277; por. V.P. Hamilton, The Book of Genesis..., s. 125. 


\begin{tabular}{l|l|l|l}
\hline „Śmierć i pogrzeb żony & $23,1-20$ & $35,18-20$ & 48,7 \\
\hline Małżeństwo syna & $24,1-67$ & $35,21-22$ & $49,3-4$ \\
\hline Lista potomków & $25,1-6$ & $35,22-26$ & $49,5-28$ \\
\hline Śmierć i pogrzeb patriarchy & $25,7-10$ & $35,27-29$ & $49,29-50,14$ \\
\hline Lista potomków & $25,12-17$ & $36,1-42$ & \\
\hline «Oto są dzieje potomków...» & 25,19 & 37,2 ”25. & \\
\hline
\end{tabular}

Jego zdaniem jest to wyraźny zabieg redaktora Księgi Rodzaju, jednak nie rozwija tego wątku w dalszym ciągu prowadzonej egzegezy.

Zauważone przez Wenhama podobieństwa zakończeń cyklów poświęconych patriarchom przywołuje Bruce K. Waltke. Co ciekawe, służą mu one jako potwierdzenie przyjętego przez niego podziału treści we fragmencie Rdz 22,2025,11 , który różni się od podziału wskazanego przez powyższy schemat ${ }^{26}$. Niestety jest to jedyny sposób, w jaki wykorzystuje tę informację.

Zostaje zatem wskazane zestawienie struktur zawierających okoliczności śmierci trzech wielkich patriarchów. Niestety nie zostało ono szczegółowo omówione przez żadnego z autorów. Nie wskazano również wniosków teologicznych płynących z tego zestawienia, poza uzasadnieniem podziału treści Księgi Rodzaju w odniesieniu do Abrahama.

\section{Grób patriarchów a tzw. „hipoteza północna”}

Opracowaniem, które próbuje objąć tematykę dotyczącą śmierci wszystkich patriarchów opisaną w Księdze Rodzaju, jest artykuł Samuela E. Loewenstamma. W początkowych rozważaniach ukazuje, że czynnikiem wyróżniającym opisy śmierci patriarchów jest kwestia podania liczby lat, które przeżyli, oraz fakt, że ich życie osiągnęło pełnię ${ }^{27}$. W tym kontekście może trochę dziwić wykluczenie Rdz 23,1, gdzie mamy bardzo wyraźną informację o liczbie lat życia Sary, ale jego zdaniem opisy śmierci kobiet, jeśli pojawiają się w Księdze Rodzaju, odgrywają drugorzędną rolę jako element jakiegoś ważniejszego motywu:

Śmierć Sary służy jako wyjaśnienie wstępu do opowieści o nabyciu jaskini Makpela, natomiast w opowieści o śmierci Racheli istotne są dwa motywy etiolo-

${ }^{25}$ G.J. Wenham, Genesis..., s. 156 (thum. M. Basiuk).

${ }^{26}$ B.K. Waltke, Genesis..., s. 312.

27 S.E. Loewenstamm, The Death of the Patriarchs in the Book of Genesis [w:] tenże, From Babylon to Canaan. Studies in the Bible and Its Oriental Background, Jerusalem 1992, s. 78-108, tu: s. 78-79. 
giczne: wyjaśnienie imienia Benjamina, które obejmuje system historiografii (por.

$29,32-30,24)$ i wyjaśnienie nazwy steli postawionej nad jej grobem $(35,20)^{28}$.

Zdaniem Loewenstamma opis śmierci Abrahama (Rdz 25,8-11) stanowi wzór dla pozostałych opisów ${ }^{29}$. Krótko zostają omówione podobieństwa, które można odnaleźć w opisach śmierci Izaaka, Izmaela i Sary ${ }^{30}$. Autor natomiast koncentruje się na podobieństwach zawartych w perykopie dotyczącej śmierci Jakuba, co wynika z samej długości tego tekstu (opisowi śmierci Abrahama poświęcone są w Biblii cztery wersety, Izaaka dwa, natomiast opis śmierci Jakuba to tekst: Rdz 47,28-50,14) oraz jego złożoności (tradycyjnie różne fragmenty tej perykopy zaliczane są do źródeł J, E i P) ${ }^{31}$. W swoich rozważaniach badacz rozróżnia natomiast dwie tradycje dotyczące śmierci Jakuba: południową (zawiera głównie teksty pochodzące ze źródła P), lokującą grób patriarchy w pieczarze Makpela, i północną, która jego pochówek łączy z Sychem ${ }^{32}$. Jak Loewenstamm sam stwierdza, jego podział jest elastyczniejszy od klasycznego przyjętego w hipotezie źródeł, ponieważ pozwala na wprowadzenie jeszcze dodatkowych tradycji ${ }^{33}$. Ostateczną konkluzją jest stwierdzenie, że miejscem pochówku Jakuba według tradycji judzkiej jest pieczara Makpela, według tradycji z Betel jest nim grób Racheli, a tradycja z Sychem ma wskazywać na grób Józefa. Zdaniem Loewenstamma $z$ tradycji północnej na etapie prac redakcyjnych mających na celu scalenie jej z tradycją południową usunięto informacje o momencie śmierci i pogrzebie $J$ Jakuba $^{34}$. Pomimo różnic wszystkie te tradycje mają wspólny element, którym jest pochowanie Jakuba w ziemi Kanaan, a nie w Egipcie ${ }^{35}$.

\section{Opowieści na lożu śmierci}

Kerry D. Lee w swojej monografii dotyczącej analizy narracji o śmierci Jakuba w Księdze Rodzaju definiuje w ramach założeń wstępnych występowanie tzw. standardowych hebrajskich opowieści na łożu śmierci (the conventional Hebrew

${ }^{28}$ Tamże, s. 78 (tłum. M. Basiuk). W dalszych rozważaniach pojawia się co prawda wzmianka o wyjątkowości informacji podającej wiek Sary w chwili śmierci, ale zostaje ona pozostawiona bez komentarza. Zob. tamże, s. 80.

${ }_{29}$ Tamże, s. 80-81.

30 Tamże, s. 81-82.

31 Tamże, s. 83.

32 Za taką lokalizacją grobu Jakuba opowiada się również Elizabeth Bloch-Smith. Zob. taż, Judahite Burial Practices and Beliefs about the Dead, Sheffield 1992, s. 114.

${ }^{33}$ S.E. Loewenstamm, The Death ..., s. 103-107.

${ }^{34}$ Tamże, s. 85.

${ }^{35}$ Tamże, s. 107. 
deathbed story) ${ }^{36}$. Jako takie przyjmuje narracje, które relacjonują ostatnie słowa i czyny postaci wyróżnionych przez narratora, a także wykonanie ostatnich pragnień tych postaci ${ }^{37}$. W tekstach biblijnych i pozabiblijnych wskazuje na następujące narracje jako spełniające podane kryteria:

Rdz 24,1-25,11 (Abraham); Rdz 27,1-35,29, szczególnie 27,1-28,9 i 35,22b-29 (Izaak); Rdz 47,28-50,26 (Jakub); Rdz 50,22-26 (Józef); Pwt, szczególnie rozdziały 31-34 (Mojżesz); Joz 13,1-24,33, szczególnie 13,1-7 i 23,1-24,33 (Jozue); Sdz 8,22-32 (Gedeon); 1 Sm 8,1-31,13 (Samuel); 2 Sm 23,1-7 (Dawid); $1 \mathrm{Krl}$ 1,1-2,46 (Dawid); 2 Krl 2,1-25 (Eliasz); 2 Krl 13,14-25 (Elizeusz); 2 Krl 20,1-11 (Ezechiasz); 1 Krn 23-29 (Dawid); 1 Mch 2,49-70 (Matatiasz); Tb 4,1-14,15, szczególnie 4,1-5,3 i 13-14 (Tobiasz); Jdt 15-16 (Judyta); Testament Dwunastu Patriarchów (dwunastu synów Jakuba) ${ }^{38}$.

Każda opowieść na łożu śmierci według Lee musi zawierać co najmniej jeden cykl składający się z elementów pochodzących z kategorii: przygotowanie, testament, konkluzja. Ponadto w ramach pojedynczego cyklu mogą się pojawiać elementy z dodatkowych kategorii takich jak: wybór godnego następcy oraz motywy strukturalnie niezależne ${ }^{39}$. Aby zobrazować swoje przemyślenia, Lee prezentuje krótki opis oraz strukturę wskazującą występowanie poszczególnych elementów standardowych opowieści na łożu śmierci odnoszącą się do narracji wymienionych wyżej ${ }^{40}$. W dalszej części monografii przechodzi z kolei do szczegółowego omówienia dwóch z nich odnoszących się odpowiednio do osoby Jakuba i Józefa. Konkludując, należy podkreślić, że badania Lee, mimo że poświęcone są w głównej mierze jedynie dwóm patriarchom, wskazują na pewien element wspólny odnoszący się do wszystkich patriarchów w kontekście związanym z ich śmiercią.

\section{Podsumowanie}

Dzięki dużej liczbie komentarzy i szczegółowych opracowań dotyczących Księgi Rodzaju wiele tekstów w niej zawartych jest dobrze przebadanych. Często

${ }^{36}$ Badania Lee opierają się na pracach Vladimira Proppa, który opisał wspólną strukturę leżącą u podłoża około stu rosyjskich bajek. Zob. K.D. Lee, The death of Jacob ..., s. 17-22.

37 Tamże, s. 25.

38 Tamże, s. 28 (tłum. M. Basiuk).

${ }^{39}$ Lee w każdej z wymienionych kategorii wyróżnia różne motywy, które mogą się w niej pojawić, a opatrując je odpowiednimi oznaczeniami, tworzy zestaw symboli pomocnych we właściwym kategoryzowaniu konkretnych fragmentów analizowanych tekstów. Zob. tamże, s. 29-37.

${ }^{40}$ Tamże, s. 37-63. 
podkreśla się również relacje zachodzące pomiędzy występującymi w niej narracjami, które wskazują na pewne wątki istotne nie tylko dla teologii tej księgi, ale również dla nauczania zawartego w Starym Testamencie czy też w całym Piśmie Świętym. Przykładem takich tematów, które doczekały się wielu dobrych i często przekrojowych opracowań, może być dzieło stwórcze Boga czy też obietnice złożone Abrahamowi. Jednak jak ukazuje ten zwięzły przegląd stanu badań dotyczący pogrzebu i grobu w historii patriarchów, są w Księdze Rodzaju teksty, które nie zostały tak gruntownie przebadane i wciąż stanowią materiał oczekujący na poddanie go dogłębnym analizom.

Temat wydarzeń towarzyszących śmierci patriarchów, takich jak pogrzeb, żałoba czy grób, poruszany jest zazwyczaj jedynie w kontekście końca życia konkretnego patriarchy. Jednak, jak można było zauważyć, niewiele jest opracowań starających się wskazać wspólne odniesienia dotyczące tych narracji. Co więcej, istniejące teksty pozostawiają pewien niedosyt, ponieważ nawet jeśli początkowo sugerują całościowe spojrzenie na problematykę śmierci patriarchów, to ostatecznie koncentrują się na wydarzeniach odnoszących się do jednego z nich. Taki stan rzeczy jest wyraźnym zaproszeniem do podjęcia dalszych badań w celu rozwinięcia zawartych $\mathrm{w}$ tych publikacjach intuicji.

\section{The funeral and the grave in the traditions about patriarchs described in the Book of Genesis. The state of research}

\section{Summary}

In the sanctuary dedicated to the patriarchs in Hebron, according to tradition, there are graves of Abraham, Isaac and Jacob and their wives, Sarah, Rebekah and Leah. The roots of this tradition go back to the Book of Genesis, however, today there are some people who call into question the credibility of this message. On the grounds of analysis of the text describing the circumstances of Jacob's death, some state that actually his grave has a different location. Others, in turn, will point out that the story of Abraham purchasing a field with the cave of Machpelah for the grave of Sarah (cf. Gen 23) is a very late tradition, which was attached to the pre-existing text. Therefore, in this article, we will analyze existing studies referring to the issue of the patriarchs' death and its accompanying events (funeral, mourning, grave) in order to check how they discuss it and to what extent they approach this practice globally.

\section{Keywords}

funeral, grave, death, patriarchs, Hebron 


\section{Słowa kluczowe}

pogrzeb, grób, śmierć, patriarchowie, Hebron

\section{Bibliografia}

Arden-Close Ch.F., The Cave of Machpelah, „Palestine Exploration Quarterly” 82 (1950) 1, s. 69-77.

Berman J., Identity Politics and the Burial of Jacob (Genesis 50:1-14), „,The Catholic Biblical Quarterly" 68 (2006) 1, s. 11-31.

Bloch-Smith E., Judahite Burial Practices and Beliefs about the Dead, Sheffield 1992.

Bray J.S., Genesis 23 - A Priestly Paradigm for Burial, ,Journal for the Study of the Old Testament" 60 (1993), s. 69-73.

Brodie T.L., Genesis as Dialogue. A Literary, Historical, and Theological Commentary, New York 2001.

Brueggemann W., Genesis, Louisville 1982.

Coats G.W., Genesis with an Introduction to Narrative Literature, Grand Rapids 1983.

Cotter D.W., Genesis, Collegeville 2003.

Free J.P., Vos H.F., Archaeology and Bible History, Grand Rapids 1992.

Gunkel H., Genesis, Göttingen 1964'

Hamilton V.P., The Book of Genesis. Chapters 18-50, Grand Rapids 1995.

Łach S., Księga Rodzaju. Wstęp - przekład z oryginału - komentarz, Poznań 1962.

Lee K.D., The death of Jacob. Narrative conventions in Genesis 47.28-50.26, Leiden 2016.

Lehmann M.R., Abraham's Purchase of Machpelah and Hittite Law, „Bulletin of the American Schools of Oriental Research" 129 (1953), s. 15-18.

Lemański J., Grób jako znak prawa własności ziemi? Rdz 23 i jego przesłanie teologiczne, „Roczniki biblijne” 1 (2009), s. 127-153.

Lemański J., Księga Rodzaju. Rozdziały 11,27-36,43. Wstęp, przekład z oryginału, komentarz, Częstochowa 2014.

Lemański J., Księga Rodzaju. Rozdziały 37-50. Wstęp, przekład z oryginału, komentarz, Częstochowa 2015.

Loewenstamm S.E., The Death of the Patriarchs in the Book of Genesis [w:] tenże, From

Babylon to Canaan. Studies in the Bible and Its Oriental Background, Jerusalem 1992, s. 78-108.

MacDonald N., Driving a Hard Bargain? Genesis 23 and Models of Economic Exchange [w:] Anthropology and Biblical Studies. Avenues of Approach, ed. by L.J. Lawrence, M.I. Aguilar, Leiden 2004, s. 79-96.

Mathews K.A., Genesis 11:27-50:26, Nashville 2005.

McKeown J., Genesis, Grand Rapids 2008. 
Miller N., Patriarchal Burial Site Explored for First Time in 700 Years, „Biblical Archaeology Review" 11 (1995) 3, s. 26-30, 34-43.

News Agency NAI, Hidden Until Now: Abraham's Burial Site, http://www.khouse.org/ articles/1997/13/ [dostęp 12.09.2018].

Niesiołowski-Spanò Ł., Mityczne początki miejsc świętych w Starym Testamencie, Warszawa 2003.

Rad G. von, Genesis. A Commentary (Revised edition), Philadelphia 1972.

Russell S.C., Abraham's Purchase of Ephron's Land in Anthropological Perspective, „Biblical Interpretation" 21 (2013) 2, s. 153-170.

Sarna N.M., Genesis, Philadelphia 1989.

Skinner J., A Critical and Exegetical Commentary on Genesis, Edinburgh 1951.

Tucker G.M., The Legal Background of Genesis 23, „Journal of Biblical Literature” 85 (1966), s. 77-84.

Vincent L.H., La sepulture des Patriarches d'apres la Bible, „Revue Biblique” 29 (1920) 4, s. 507-539.

Vincent L.H., Mackay E.J.H., Hebron - Le Haram el-Khalil - Sépulture des Patriarches, Paris 1923.

Waltke B.K., Genesis. A Commentary, Grand Rapids 2001.

Wenham G.J., Genesis 16-50, Dallas 1994.

Westermann C., Genesis 12-50, Neukirchen-Vluyn 1981. 